Open Access

\title{
The impact of usable system for regression analysis in higher education
}

Ricardo Adán Salas-Rueda

\section{Correspondence:}

ricardoadansalasrueda@hotmail.com Universidad La Salle, México,

Benjamín Franklin 47, Col. Condesa, Del. Cuauhtémoc, México, DF, CP 06140, Mexico

\begin{abstract}
In Mexico, both universities and professors are changing the teaching-learning process in order to improve the conditions that prevail in the classroom. These modifications are making instructors include the usage, planning, organization, and construction of various technological applications in their activities. This research proposes the design and implementation of System Usable for Regression Analysis (SUAR), the purpose of which is to customize the audiovisual content taking into account the characteristics and abilities of the students. In particular, this system adjusts the information considering the level of knowledge of the estimation of prediction and visual or auditory learning styles by the adaptation, content, and evaluation modules. This study is based on the quantitative approach to analyze the academic performance of 14 students taking the System Design course during the school year 2015-I. The ANOVA method with the significance level of 0.05 and 0.025 assess the impact of SUAR during this course accomplished at a university in the south of Mexico City. Finally, this investigation proposes to build web systems that consider SUAR architecture and usability to enhance the educational context.
\end{abstract}

Keywords: Computer-assisted instruction, Online learning, Distance learning, Usability

\section{Introduction}

Today, universities in Mexico are modifying their activities, methodologies and processes of teaching-learning in order to meet the demands of the students in the XXI century. To perform these transformations efficiently, the colleges analyze the prevailing conditions in the environment to redefine the people's profile involved in education. In particular, Monereo \& y Domínguez (2014, p.86) state that the teacher should develop "innovation competition which includes actions such as the inclusion of changes that optimize the educational process, analysis, inquiry and reflection on one's own experience or participation in projects and quality improvement".

According to Vázquez García (2015), one of the global trends that is influencing higher education is the online component, which involves the use of the network, Internet and new technologies for personalized information. Similarly, Ariza and Quesada (2014) explain that there is a growing tendency among professors regarding the use of technological tools which highlights the importance of the digital material's design (videos, tutorials and assessment questions banks) to acquire and to achieve lasting and transferable knowledge.

(C) 2016 Salas-Rueda. Open Access This article is distributed under the terms of the Creative Commons Attribution 4.0 International License (http://creativecommons.org/licenses/by/4.0/), which permits unrestricted use, distribution, and reproduction in any medium, provided you give appropriate credit to the original author(s) and the source, provide a link to the Creative Commons license, and indicate if changes were made. 
Hepp, Prats Fernández, and Holgado Garcia (2015) established that the new learning scenarios have a transformative perspective that includes the training of tutors in relation to the educational innovations and technology where digital, open, flexible, creative, real, and participatory projects are incorporated. Also, Ongun and Demirag (2015) claim that students using multimedia resources can significantly plan their tasks through the use of visual and audio tools.

In fact, instructors get involved every day in the aspects of planning, evaluation and implementation of various software applications used in the classroom, where the aspect of usability has a preponderant importance to facilitate the assimilation and reuse of knowledge.

With this background in mind, during the 2015-I cycle, the "Systems Design" course educator has decided to build the System Usable for Regression Analysis (SUAR) in order to evaluate the teaching-learning process about the design of intelligent applications.

This study is structured as follows: the importance of usability is reviewed in the first section and the following sections describe the methodology, results, and conclusions of this investigation.

\section{Usability}

González and Farnós (2009) mention that usability refers to the degree of ease in the use of a type of product (technology) and satisfaction generated in the people characterized by the speed of access and understanding. Similarly, Ruiz et al., (2006 p.27) explain that the ISO/IECE 9126 rule states that "usability is the ability of a software product to be understood, learned and attractive to the people when it is employed under specific conditions".

According to Turpo Gebera (2012), it is essential to consider usability during the organization, the development, and the evaluation of an online training to ensure student learning and the quality of the resources. Alva (2005) suggests the analysis of usability for online academic resources through three dimensions: navigation, design, and content (see Table 1).

Mascheroni, Greiner, Dapozo, \& y Estayno (2013 p.126) indicate that Usability Engineering (UI) can be defined as "a set of techniques for the development of systems in which is specified the quantitative levels of utility and is constructed to achieve those levels, known as metrics". Table 2 shows the stages of UI.

Finally, Leavitt and Shneiderman (2006) explain that the guidelines of the US Department of Health and Human Services (HHS) contain the most important features of international standards of usability for web design. In particular, the category called Process of design and evaluation allows one to analyze the use of the content for the audience, to identify the needs of the last user, to determine the interaction with the user and to assess the technological advances.

\section{Methodology}

This research is based on the quantitative approach in order to analyze the academic performance of students before and after using the SUAR in the Systems Design course. According to Giroux and Tremblay (2004), this approach allows for the analyzing of the phenomena through measurement and data analysis with numbers. Furthermore Newbold, Carlson, and Thorne (2008) explained that the quantitative data have measurable meaning, which can be calculated at intervals and reasons. 
Table 1 Dimensions for usability analysis

\begin{tabular}{|c|c|c|c|}
\hline No & Navigation & Design & Content \\
\hline 1 & Moving between pages of the site & Types of messages & Release date \\
\hline 2 & Friendly navigation & Equality use & Bug free \\
\hline 3 & Links and labeling & Flexibility & Content adjusted to the pedagogical level \\
\hline 4 & Ease of user location & Simple and intuitive & Links to information sources \\
\hline 5 & Ease of sending and receiving & $\begin{array}{l}\text { Appropriate } \\
\text { dimensions }\end{array}$ & Name and credentials of the author \\
\hline 6 & $\begin{array}{l}\text { Visible and easily identifiable } \\
\text { options }\end{array}$ & Fault tolerant & Specific frames \\
\hline 7 & Simple language & Little physical effort & $\begin{array}{l}\text { Content in perspective and without } \\
\text { distortion }\end{array}$ \\
\hline 8 & & $\begin{array}{l}\text { Perceptible } \\
\text { information }\end{array}$ & Minimization of the use of notifications \\
\hline 9 & & & Learning objectives \\
\hline 10 & & & Learning path \\
\hline 11 & & & Previous knowledge required \\
\hline 12 & & & Learning levels \\
\hline
\end{tabular}

According to Keller (2012), inferential statistics is the process of making an estimate, prediction, or decision about a population based on a sample. Similarly, Casas Sánchez (2010), p.20) states that "when a sample of a population is selected, a key objective is to make inferences about population characteristics or draw conclusions that are valid for the entire population".

In this research, the sample consisted of 14 students enrolled in the Systems Design course during the school year 2015-I where SUAR is used to present the content about the regression analysis for the construction of intelligent systems. It is noteworthy that it determines the correlation between different variables in order to estimate the prediction through different types of mathematical models as linear or quadratic (Walpole, Myers, Ye, \& y Myers, 2012).

The general objective of this investigation is: design, implement and evaluate the SUAR in the Systems Design course during the 2015-I cycle.

Table 2 Stages of usability engineering

\begin{tabular}{|c|c|c|}
\hline Stage & Element & Description \\
\hline \multirow[t]{3}{*}{ Specifications } & Users' analysis & It is done to identify the users and their tasks, and the way they carry them out \\
\hline & $\begin{array}{l}\text { Task } \\
\text { Identification }\end{array}$ & It is a set of techniques used to determine how users perform a specific task \\
\hline & $\begin{array}{l}\text { Specifying } \\
\text { usability }\end{array}$ & It refers to a series of usability specifications \\
\hline \multirow[t]{3}{*}{ Design } & $\begin{array}{l}\text { Interaction } \\
\text { design }\end{array}$ & It includes a conceptual system and a visual interaction design \\
\hline & Prototype & Precise system prototypes are used to be easily understood by the user \\
\hline & $\begin{array}{l}\text { User's } \\
\text { participation }\end{array}$ & $\begin{array}{l}\text { The participation at this stage can vary according to the degree of involvement, } \\
\text { providing a User Centered Design (UCD) or Participatory Design (PD) }\end{array}$ \\
\hline \multirow[t]{2}{*}{ Evaluation } & $\begin{array}{l}\text { Usability } \\
\text { testing }\end{array}$ & $\begin{array}{l}\text { It shows the user a set of tasks to be performed with the previously designed } \\
\text { prototype, compiling their actions and evaluation to be analyzed later }\end{array}$ \\
\hline & $\begin{array}{l}\text { Heuristic } \\
\text { evaluation }\end{array}$ & $\begin{array}{l}\text { This evaluation is based on experience of design or usability guidelines to point } \\
\text { out the mistakes in the system }\end{array}$ \\
\hline
\end{tabular}


The specific objectives for this research are: design the SUAR considering the aspect of usability, implementing SUAR in the Systems Design course during the school year 2015-I, and assess the impact of SUAR during the process of teaching-learning through the ANOVA method.

Anderson, (Anderson, Sweeney, \& Williams, (2008):497) state that the ANOVA method "allows the obtaining of two independent estimates of the common population variance $\sigma^{2}$. One estimate of $\sigma^{2}$ is based on the variability between the sample means and the variability between each sample data".

The independent variable for this investigation is the SUAR and the dependent variable is related to the student's performance (grade). The research's tool consists of two questionnaires about the design of intelligent systems considering regression analysis, which are used before and after the students employ this technological tool. Figure 1 shows the questionnaire used to retrieve information about the students before and after using the SUAR.

Furthermore, this study used a questionnaire to retrieve student impressions on the aspect of usability used in the SUAR (See Table 3).

The hypotheses of this investigation are:

Null hypothesis (Ho): The SUAR does not facilitate the teaching-learning process related to the design of intelligent systems.

Alternative hypothesis (Ha): The SUAR facilitates the teaching-learning process related to the design of intelligent systems.

\section{Results}

Figure 2 shows the web interface SUAR built through HTML5 to facilitate the access of information. According to Punín, Martínez, and Rencoret (2014), HTML5 (Hyper Text

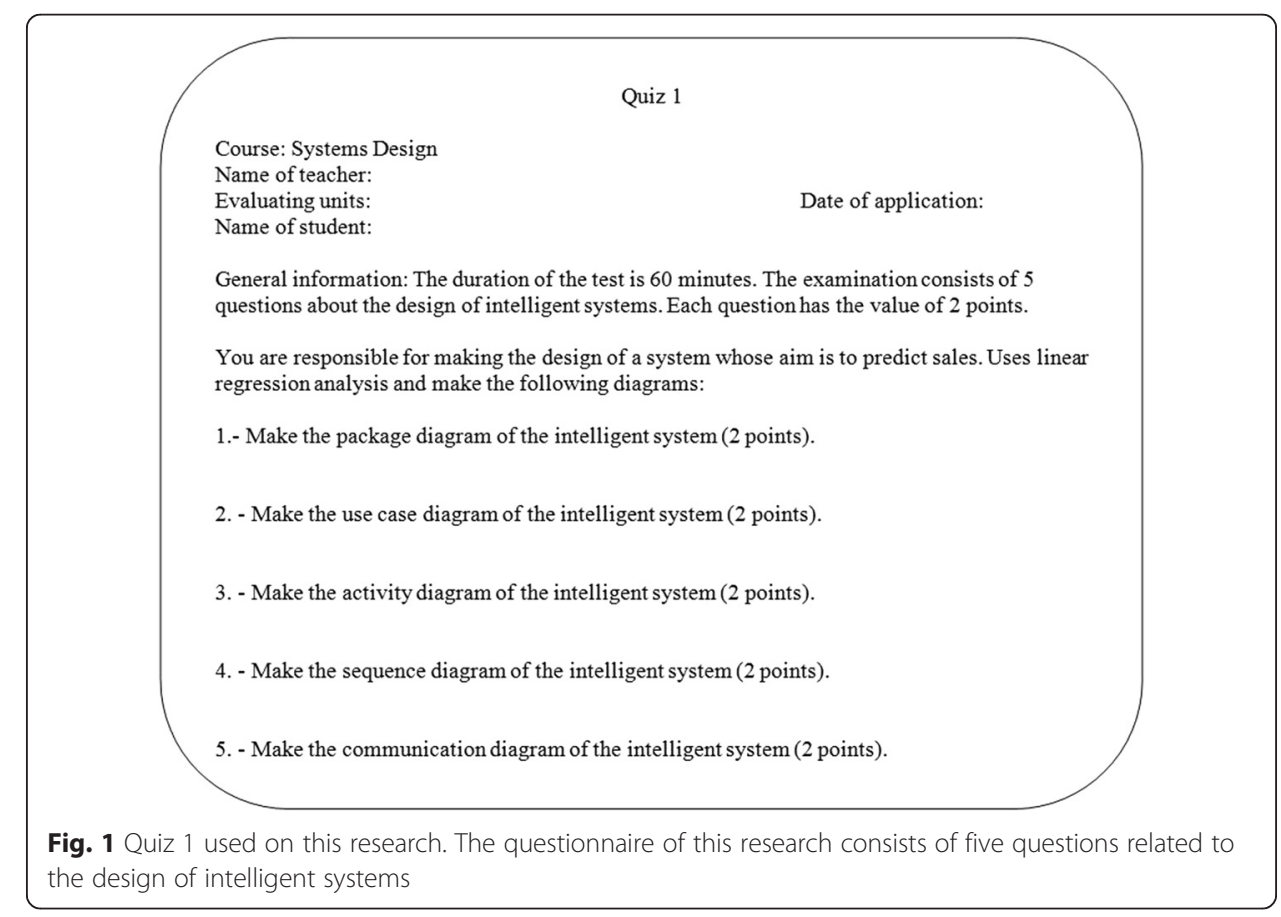


Table 3 Elements of the questionnaire on usability

\begin{tabular}{|c|c|c|c|c|c|c|}
\hline No & Categories & Variable name & Content & $\begin{array}{l}\text { Measurement } \\
\text { scale }\end{array}$ & $\begin{array}{l}\text { Modalities } \\
\text { or value }\end{array}$ & Code \\
\hline 1 & Utility & Contents & $\begin{array}{l}\text { Audiovisual content facilitates the } \\
\text { teaching-learning process related to } \\
\text { prediction }\end{array}$ & Ordinal & $\begin{array}{l}\text { Strongly } \\
\text { agree }\end{array}$ & 1 \\
\hline 2 & Utility & Personalization & $\begin{array}{l}\text { Customization of audiovisual content } \\
\text { facilitate the teaching-learning process }\end{array}$ & Ordinal & $\begin{array}{l}\text { Somewhat } \\
\text { agree }\end{array}$ & 2 \\
\hline 3 & Navigation & Web interface & $\begin{array}{l}\text { The navigation of the web interface is } \\
\text { easy }\end{array}$ & Ordinal & $\begin{array}{l}\text { Neither } \\
\text { agree nor } \\
\text { disagree }\end{array}$ & 3 \\
\hline 4 & Design & $\begin{array}{l}\text { Spanish } \\
\text { language }\end{array}$ & $\begin{array}{l}\text { Audiovisual content employing audio in } \\
\text { Spanish facilitates the teaching-learning } \\
\text { process }\end{array}$ & Ordinal & $\begin{array}{l}\text { Somewhat } \\
\text { disagree }\end{array}$ & 4 \\
\hline 5 & Design & $\begin{array}{l}\text { English } \\
\text { language }\end{array}$ & $\begin{array}{l}\text { Audiovisual content employing audio in } \\
\text { English facilitates the teaching-learning } \\
\text { process }\end{array}$ & Ordinal & $\begin{array}{l}\text { Strongly } \\
\text { disagree }\end{array}$ & 5 \\
\hline
\end{tabular}

Markup Language) allows for the creating of usable web sites through the flexibility of operating systems and browsers.

Figure 3 shows the SUAR architecture composed of Adaptation, Content, and Evaluation modules.

Adaptation module receives information from the evaluation module to select audiovisual content that adjust to the students' profile. Figure 4 presents the questionnaire used by the evaluation module to identify the level of knowledge and the visual or auditory learning styles.

The content module stores information about regression analysis considering the user's profile. For example, the visual or auditory learning styles are personalized through subtitles and audio in Spanish and English. Figure 5 shows an example of audiovisual content used by the SUAR.

Table 4 shows the objectives that are included in the category called Process design and the evaluation of HHS, which are used during the planning and construction of SUAR.

\section{Análisis y regresión de series}

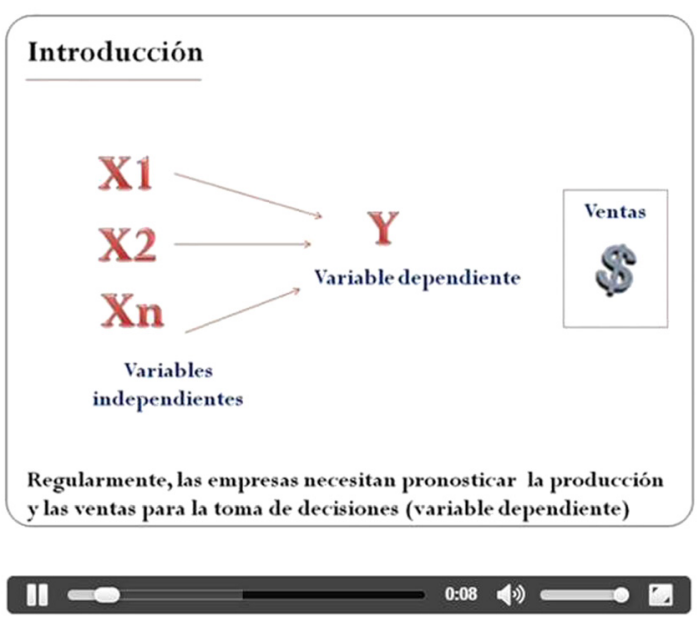

Fig. 2 Web Interface SUAR. Audiovisual content uses linear regression to the design of intelligent systems 


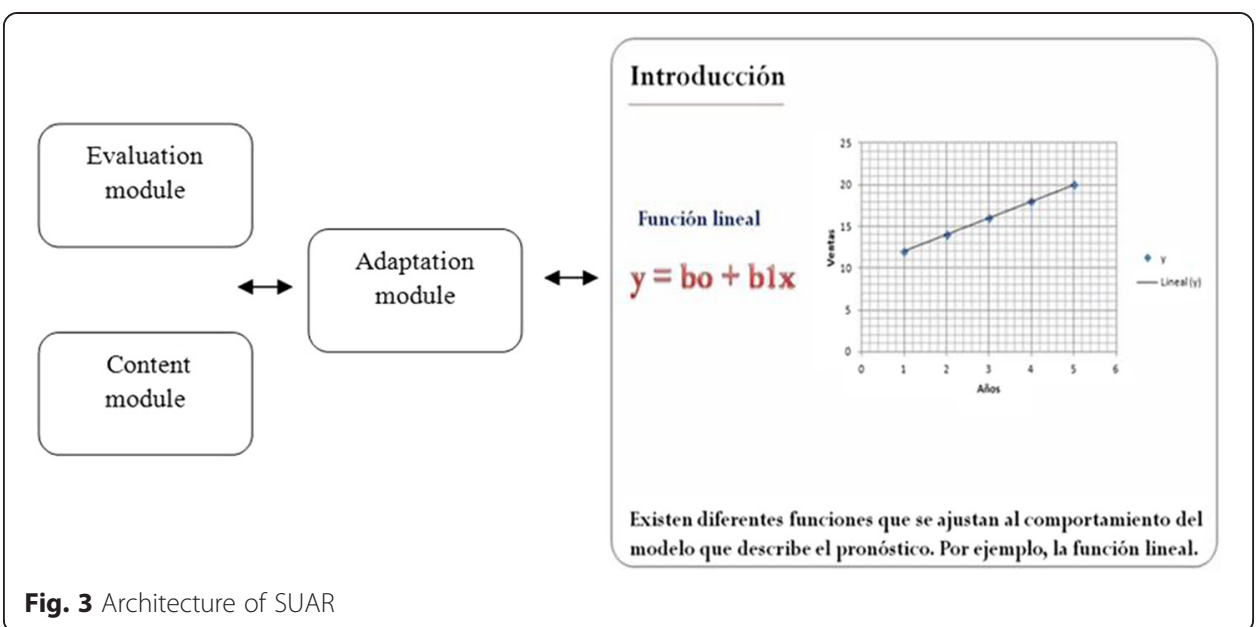

The ANOVA method allows this research to understand the behavior presented by 14 students before and after using the SUAR with a significance level of 0.05 and 0.025 . Table 5 shows the results obtained using the spreadsheet to use this method

Table 5 shows that the F (17.27) value is greater than the critical values of $0.05(4.225)$ and 0.025 (5.658). Therefore, the null hypothesis is rejected and the alternative hypothesis is accepted, which states that the SUAR improves the process of teaching-learning related to the design of intelligent systems using regression analysis to calculate the prediction.

Figure 6 shows the academic performance presented by the 14 students who completed the Systems Design course in the 2015-1 school year before and after using the SUAR.

For the analysis of the aspect of usability, this research was based on the following scale: Strongly agree (1) and strongly disagree (5). Table 6 shows the percentages obtained from the categories of utility, navigation, and design.

Table 6 shows that the prevailing opinion of the14 students regarding the three aspects of usability composed of the utility, navigation, and design categories is in the somewhat agree scale.

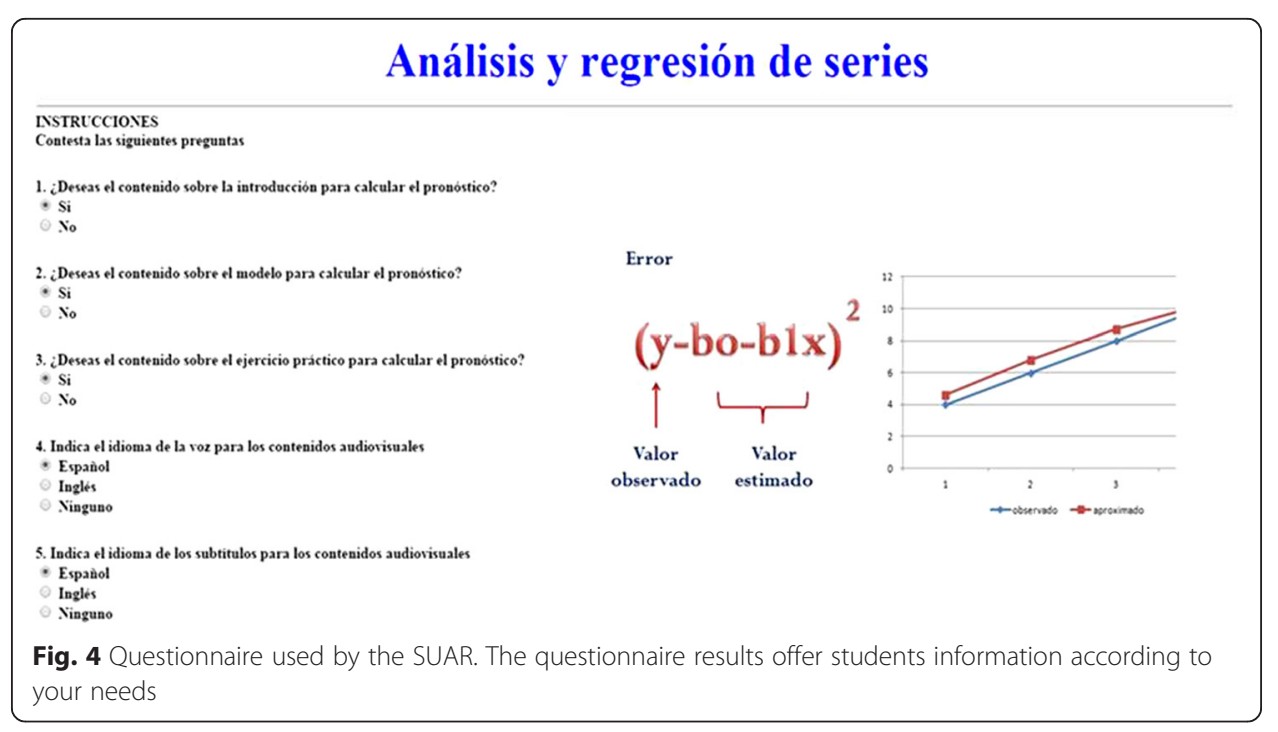




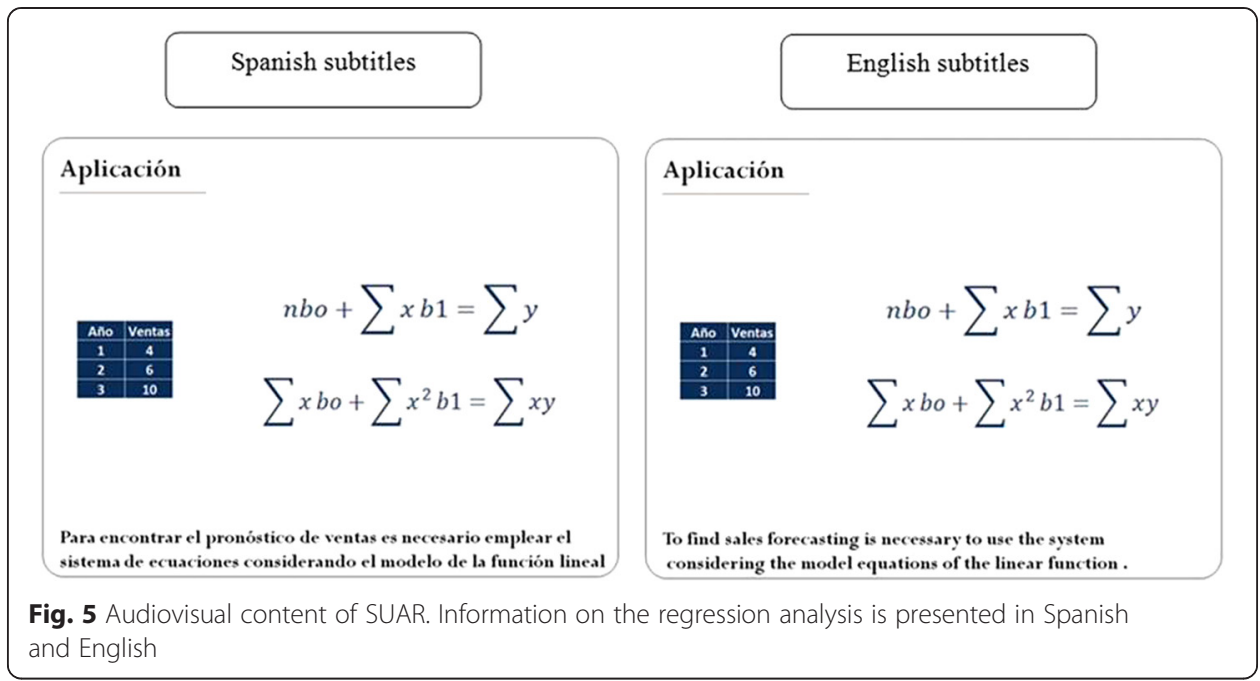

\section{Conclusion and discussion}

Nowadays, universities face new challenges related to the teaching-learning process where the design and implementation of cutting-edge technology is fundamental to meet the educational demands of the XXI century. Indeed, Pérez and Delgado (2012) mention the importance and necessity of undertaking various educational procedures in order to create competent individuals.

As reported by Rodríguez Aguilar, Castillo González, and y Liria Campos (2013), the success of significant learning through the use of ICT is related to the figures, images, animations and simulations on the web interface. In particular, the adaptation of content refers to the dynamic presentation of web pages (text, audio, sound, video and animation) taking into account the level of knowledge, goals and user characteristics (Kazanidis \& Satratzemi, 2007).

Therefore, the responsibilities, functions and activities of the professor are changing in order to improve the teaching-learning process. One aspect that allowed the realization of these modifications is the training of tutors in the aspects related to computer and instructional design.

This research proposes the design of a usable system for regression analysis (SUAR) to facilitate the assimilation and reuse of knowledge about the planning of intelligent systems dedicated to prediction. The adaptation module manages the presentation of the audiovisual content that the student needs through the selection of the level of knowledge, subtitles and audio in Spanish and English.

González Vidal and y Blanco Encinosa (2012) explain that adaptation refers to the ability of a system to meet the needs and requirements of the user. Furthermore, the Content

Table 4 Objectives of the design process and evaluation of HHS

\begin{tabular}{lll}
\hline No & Objective & Use in SUAR \\
\hline 1 & Provide useful content & $\begin{array}{l}\text { Audiovisual content considered the issues related to the regression } \\
\text { analysis used in the design of intelligent web systems. }\end{array}$ \\
$2 \quad$ Establish user requirements & $\begin{array}{l}\text { The requirements are related to the student's learning style and his } \\
\text { or her level of knowledge. }\end{array}$ \\
$3 \quad$ Consider the diversity of the interface & $\begin{array}{l}\text { Programming in HTML5 enables flexibility in the browsers and } \\
\text { operating systems used by the student }\end{array}$ \\
\hline
\end{tabular}


Table 5 ANOVA with a significance level of 0.05 and 0.025

\begin{tabular}{lllllll}
\hline Origin of variations & $\begin{array}{l}\text { Sum of } \\
\text { squares }\end{array}$ & $\begin{array}{l}\text { Degrees } \\
\text { of freedom }\end{array}$ & $\begin{array}{l}\text { Average } \\
\text { squares }\end{array}$ & $F$ & $\begin{array}{l}\text { Critical value for } \\
F(a=0.05)\end{array}$ & $\begin{array}{l}\text { Critical value for } \\
F(a=0.025)\end{array}$ \\
\hline Among groups & 30.0357143 & 1 & 30.0357143 & 17.271722 & 4.225 & 5.658 \\
Within groups & 45.2142857 & 26 & 1.73901099 & & & \\
\hline
\end{tabular}

module stores information about the calculation of the prediction and the Questionnaire module evaluates the demands of the student to determine the user's profile

During the construction of SUAR, the aspect of usability has a fundamental role in improving the educational conditions. According to Salaverría (2005), the great challenge of building web educational systems in the XXI century is to consider the aspect of usability. In this investigation, the needs and characteristics of students are used for analysis and identification, with the objective of personalizing the audiovisual content. On top of that, the web interface design considers factors of navigation to transmit knowledge about regression analysis in a quick, easy and intuitive. Similarly, Buitrón de la Torre M (2004) explains that building web systems is related to the ease of access and interaction through usability, which he considers as fundamental factors associated with people, tasks and context.

Through the quantitative approach, this study argues that the SUAR improves the learning conditions for students. In particular, the ANOVA method with a significance level of 0.05 and 0.025, analyzed 14 students who took the Systems Design course during the 2015-I cycle where a significant change occurred in the grade on the test (dependent variable) regarding the use of case, communication, activities, sequence and package diagrams focused on the prediction. As a matter of fact, Elizondo López (2002) explains that the experimental method is based on the deliberate production of phenomena to analyze their characteristics.

This research recommends building the web interface using HTML5 language to improve access to audiovisual content through the flexibility of the browsers and the operating systems. Meyer (2010) explains that HTML5 is changing the way transmitting information over the Internet is done because media products are efficiently spread

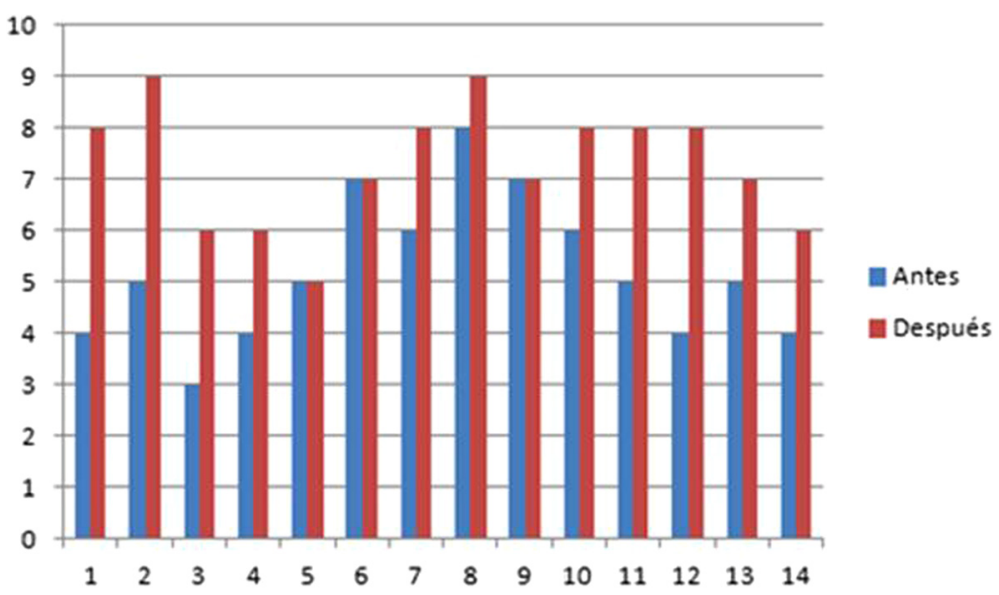

Fig. 6 Grades obtained by students. SUAR facilitates the process of teaching and learning related to the design of intelligent systems 
Table 6 Results of usability

\begin{tabular}{llll}
\hline Scale & Utility & Navigation & Design \\
\hline Strongly agree (1) & $35.71 \%$ & $35.71 \%$ & $28.57 \%$ \\
Somewhat agree (2) & $42.86 \%$ & $57.14 \%$ & $64.29 \%$ \\
Neither agree nor disagree (3) & $21.43 \%$ & $7.14 \%$ & $7.14 \%$ \\
Somewhat disagree (4) & $0.00 \%$ & $0.00 \%$ & $0.00 \%$ \\
Strongly disagree (5) & $0.00 \%$ & $0.00 \%$ & $0.00 \%$ \\
\hline
\end{tabular}

throughout various browsers (Internet Explorer, Firefox, Opera, and Chrome) and operating systems (Linux, Mac and Windows).

Similarly, this study suggests considering the characteristics of students (visual or auditory) during the planning of web-based educational systems to present information that meets their needs and expectations. Also, the aspect of usability acquires a fundamental role in the design of the teaching-learning applications because it creates nice, simple and useful virtual spaces for pupils. As Rubin and y Chisnell (2008) mentioned, usability is related to the degree to which the user achieves its objectives (utility).

This research suggests that during the design and planning of educational systems Web Adaptation, Content and Evaluation modules should be considered in order to facilitate the assimilation and reuse of knowledge. In particular, the Adaptation module presents the information according to the characteristics and needs that students have, the content module stores the data of the course and the evaluation module determines the material that the student needs through the questionnaire. Also, usable web interface allows users to receive information demanded by the customizing audiovisual content. During the system construction, it is necessary the aspects of usability related to the utility, navigation and design to be analyzed in order to create a web interface that meets the requirements of individuals. In this study, the utility is linked to content and personalization, navigation refers to the web interface and design refers to the use of Spanish and English language. $35.71 \%$ of students consider that the aspects of utility and navigation are in Category 1 (strongly agree) while $28.57 \%$ placed the design in this classification.

Note that in this investigation, the results related to usability for SUAR show that the utility (42.86\%), navigation (57.14\%) and design $(64.29 \%)$ are placed in Category 2 (somewhat agree). Therefore, SUAR architecture will be improved through the use of info graphics in order to increase the percentages obtained in Category 1 (strongly agree). Of the 14 students, 12 pupils improved their qualifications related to the design of intelligent systems and 2 obtained the same results. Through the use of the ANOVA method a value of $F$ (17.27) was obtained, which is greater than the critical values of 0.05 (4.225) and 0.025 (5.658). Therefore, the alternative hypothesis which states that the SUAR improves the process of teaching-learning related to the design of intelligent systems is accepted.

In conclusion, this study examines the design and implementation of the SUAR architecture consisting of the Adaptation, Questionnaire and Content modules to facilitate the transfer, assimilation, and reuse of knowledge explained in the classroom. In particular, this system personalizes audiovisual content in Regression Analysis to improve the teaching-learning process during the construction of intelligent applications. 


\section{Competing interests}

The author declares that he has no competing interests.

\section{Authors' information}

Doctor of Design of New Technologies, graduated from the Autonomous Metropolitan University (UAM) in 2014. For 13 years, I have taught several courses related to technology, administration, education and mathematics at the undergraduate and graduate level. During the period from 1 January 2016 to December 2018, I am a national researcher candidate by the SNI. Responsible for Group Research, Development and Innovation (GIDI) in the area of Generation and Application of Knowledge in Technology at the University La Salle.

Received: 18 December 2015 Accepted: 14 January 2016

Published online: 03 March 2016

\section{References}

Alva, M. (2005). Metodología de Medición y Evaluación de la Usabilidad en Sitios Web Educativos. España, Tesis Doctoral: Universidad de Oviedo. Retrieved from: http://di002.edv.uniovi.es/ cueva/investigacion/tesis/Elena.pdf

Anderson, D. R., Sweeney, D. J., \& Williams, T. A. (2008). Estadística para administración y economía. Distrito Federal: Cengage Learning Editores.

Ariza, M. R., \& Quesada, A. (2014). Nuevas tecnologías y aprendizaje significativo de las ciencias. Enseñanza de las Ciencias, 32(1), 101-115. http://dx.doi.org/10.5565/rev/ensciencias.433

Buitrón de la Torre, M. (2004). Consideraciones para el diseño de interfaces gráficas de usuario en ambientes virtuales educativos. UAM: Tesis de Maestría.

Casas Sánchez, J. M. (2010). Estadística económica y empresarial. Distribuciones e inferencia. Madrid: Universitaria Ramón Areces.

Elizondo López, A. (2002). Metodología de la investigación. Distrito Federal: Thomson.

Giroux, S., \& Tremblay, G. (2004). Metodología de las Ciencias Humanas. Distrito Federal: Fondo de Cultura Económica.

González Soto, A. P., \& Farnós Miró, J. D. (2009). Usabilidad y accesibilidad para un e-learning inclusivo. Revista educación inclusiva, 2(1), 49-60. Retrieved from: http://www.ujaen.es/revista/rei/linked/documentos/documentos/2-3.pdf

González Vidal, I. M., \& Blanco Encinosa, L. J. (2012). Sistemas de hipermedia adaptativa en un entorno educativo: generalidades y tendencias. COFIN Habana, 2, 62-71. Retrieved from: http://www.cofinhab.uh.cu/index.php/cofin/ article/view/65

Hepp, K., Prats Fernández, M. A., \& Holgado Garcia, J. (2015). Formación de educadores: la tecnología al servicio del desarrollo de un perfil profesional innovador y reflexivo. RUSC. Universities Knowledge Society Journal, 12(2), 30-43. doi: http://dx.doi.org/10.7238/rusc.v12i2.2458

Kazanidis, I. Y., \& Satratzemi, M. (2007). Adaptivity in a SCORM compliant adaptive educational hypermedia system. In L. Howard, L. Frederick, L. Ryson, \& L. Qing (Eds.), Advances in Web based learning (pp. 363-374). Germany, Alemania: Springer-Verlag.

Keller, G. (2012). Statistics for management and economics. Ohio: Cengage Learning.

Leavitt, M., \& Shneiderman, B. (2006). Research-based web design \& usability guidelines. Washington: GSA.

Mascheroni, M., Greiner, C., Dapozo, G., \& Estayno, M. (2013). Ingeniería de Usabilidad. Una Propuesta Tecnológica para Contribuir a la Evaluación de la Usabilidad del Software. Revista Latinoamericana de Ingeniería de Software, 1(4), 125-134. Retrieved from: http://sistemas.unla.edu.ar/sistemas/redisla/ReLAIS/relais-v1-n4-p-125-134.pdf

Meyer, J. (2010). The essential guide to HTML 5. Using games to learn HTML5 and JavaScript. Nueva York: Friendof.

Monereo, C., \& Domínguez, C. (2014). La identidad docente de los profesores universitarios competentes. Educación XX1, 17(2), 83-104. http://dx.doi.org/10.5944/educxx1.17.2.11480

Newbold, P., Carlson, W., \& Thorne, B. (2008). Estadística para administración y economía. Madrid: Prentice Hall.

Ongun, E., \& Demirag, A. (2015). El uso de multimedias en las tareas académicas por los estudiantes. Comunicar, 44(1), 121-129. http://dx.doi.org/10.3916/C44-2015-13

Pérez, M. A., \& Delgado, A. (2012). De la competencia digital y audiovisual a la competencia mediática: dimensiones e indicadores. Comunicar, 39, 25-34. http://10.3916/C39-2012-02-02

Pérez-Rodríguez, M. A., \& Delgado, Á. (2012). De la competencia digital y audiovisual a la competencia mediática: dimensiones e indicadores [From Digital and Audiovisual Competence to Media Competence: Dimensions and indicators]. Comunicar, 39, 25-34. http://dx.doi.org/10.3916/C39-2012-02-02

Punín, M. I., Martínez, A., \& Rencoret, N. (2014). Medios digitales en Ecuador: perspectivas de futuro. Comunicar, 42(XXI), 199-207. http://10.3916/C42-2014-20

Rodríguez Aguilar, R. M., Castillo González, J. L., Liria Campos, A. L. (2013). Diseño de un sistema tutor inteligente. Apertura, 5(1). Retrieved from: http://www.udgvirtual.udg.mx/apertura/index.php/apertura3/article/view/371

Rubin, J., \& y Chisnell, D. (2008). Handbook of usability testing. How to plan, design and conduct effective tests. California: Wiley.

Ruiz, G. A., Peña, A., Castro, C. A., Alaguna, A., Areiza, L., \& Rincón, R. D. (2006). Modelo de Evaluación de Calidad de Software Basado en Lógica Difusa, Aplicada a Métricas de Usabilidad de Acuerdo con la Norma ISO/IEC 9126. Avances en Sistemas e Informática, 3(2), 25-29. Retrieved from: http://www.redalyc.org/pdf/1331/133114988005.pdf

Salaverría, R. (2005). Cibermedios: el impacto de Internet en los medios de comunicación en España. Madrid: Comunicación Social.

Turpo Gebera, O. (2012). Criterios de valoración sobre la usabilidad pedagógica en la formación continua docente. Razón y palabra, 48, 64-73. Retrieved from: http://www.razonypalabra.org.mx/N/N81/N81/03_Turpo_V81.pdf

Vázquez García, J. A. (2015). Nuevos escenarios y tendencias universitarias. Revista de Investigación Educativa, 33(1), 13-26. Retrieved from: http://revistas.um.es/rie/article/view/211501/172421

Walpole, R. E., Myers, H. R., Ye, K., \& Myers, S. L. (2012). Probability \& statistics for engineers \& scientists. Massachusetts: Prentice Hall. 